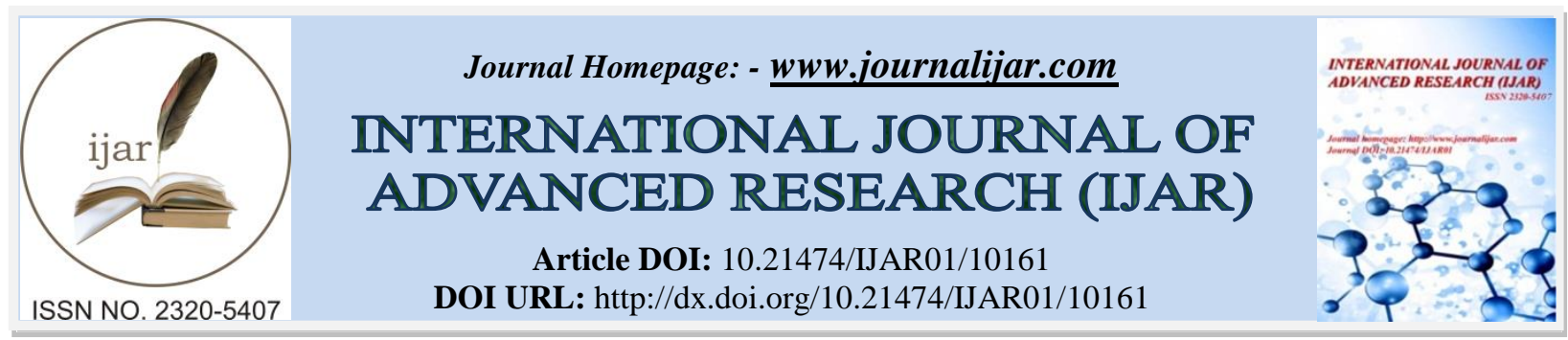

RESEARCH ARTICLE

\title{
MORALE AND ITS IMPACT ON ORGANIZATIONAL PERFORMANCE IN NEPAL AIRLINES CORPORATION IN NEPAL.
}

Rishikesh Panthi.

$\mathrm{PhD}$. Scholar, Faculty of Management, Tribhuvan University, Nepal.

\section{Manuscript Info}

\section{Manuscript History}

Received: 03 October 2019

Final Accepted: 05 November 2019

Published: December 2019

\section{Abstract}

Morale is defined as the depiction of emotion, satisfaction, and overall attitude towards a workforce. Performance is directly related to morale. Happy employees have high morale while dissatisfied and unhappy employees have low morale. The study investigates the employee Morale and its impact on organizational performance in Nepal Airlines Corporation in Nepal.75 out of 1200 respondents was selected as a sample population. Mixed methods was used. Data collected through the structured questionnaire and some keys personnel of the NAC was interviewed. The study used descriptive statistics tools for data analysis. The study shows that the employee's morale and its significant impact on employee's performance at Nepal Airlines Corporation. The Level of morale and organization performance both found moderate level. The most important factor-contributing employees morale are: salary and benefit, team spirit in direct work environment, working condition of work place, leave and holidays provided, safety and health condition, organizational culture and climate, channel of communication, relations between supervisor, subordinator, management and employees, delegation of power and authority, participation on decision making process, rewards and punishment system, fair and sound career development or promotion system, recognition of work, job satisfaction, prestige of job in the society,job placement, high degree of interest in job, organizational leadership, labour turnover, employees absenteeism, antagonism, quality output, and get happiness in organization etc. was found important factors for determines the employees motivation in the organization.

Copy Right, IJAR, 2019,. All rights reserved.

\section{Introduction:-}

\section{Background of the study:}

Nepal Airlines Corporation the than Royal Nepal Airlines Corporation was established on July 01, 1958 as the national flag carrier in Nepal. It has been considered as the geographical and cultural bridge connecting Nepal within and beyond the country. Initially it started glorious aviation landmarks of airlines business with its DC-3 Docota aircraft with 97 employees in 1958. From 1958 onwards fleet expansion process accelerated till the induction of two Airbus-A-330-200 in the year 2018 in its fleets, totaling 19 aircrafts including few other twin otters, Avro, Focker, a couple of Boeings 727, \& Airbus A-320 \& A-330. The airlines were on growth stage until 
1990, which was also marked as golden era in the history of the airline in Nepal. During that time, it had four jet aircrafts, three Hawker Siddeley (HS), four Avro, ten Twin otters and two Pilatus porters. The airlines had spread its wings from Japan in east to Europe in west as international sector and made 40 domestic operations within the country (Panthi, 2019a). It is also customary with RA to have the air business difficulties as RA decided to stop its Europe Operation in 2001. Later withdraw the number of flights in Frankfurt (FRA), London (LHR) and Peris (CDG) by the year 2001. In addition, RA also was stopped to operate flight to Osaka. Shangai and Japan which was operating over 13 years. Furthermore the flight to Colombo (CMB), Rangoon (RGN) Karachi (KHI), Dhaka (DAC) and Male (MLE) sectors were also stopped Besides national flag carrier used to provide chartered flights for UN and British Gorkha-Regiments was also stopped (Panthi, 2019 a). It was obvious that curtailment of such international flights put RA in critical position for its sustenance. On the other hand, the liberalization policy in the airline sector also affected RA in critical position to compete with other international airline services. At present, RA has been operating in nine international destinations. It is also pity that RA occupies only five aircrafts for international flights. Of them, one is 33 year old. In addition, RA has three twin otters, two MA60, and two more 2 Y12 in the inventory. At present, NAC has been running with a small number of aircrafts to operate in domestic or international destinations. In this content, it is also interesting to what extent NAC has been performing which enable to sustain and maintain regular services to its clients.

The airlines has recently moderated it's organization set up for greater efficiency, productivity, transparency, accountability and improve the standard quality services in keeping with changing global market environment. In order to meet these challenges successfully. It needs human resource planning as regularly, properly and fulfillment of demands of employees. Improve the high motivation of the employees and maintain their morale to achieve the vision, mission, goals, and objectives of NAC.

Every organization performs its task with the help of resources as men, machine, materials, methods, money and information or $5 \mathrm{M}+\mathrm{I}$. Except employee, the other resources are non-living but employee is a live and most important element in the management. Out of these all the factors of production, employees has the highest priority and is the most significant factor of production and play the pivotal role in areas of production, productivity, quality, and overall outputs or performance of the organization. Employee is an important asset for any organization, with most organization sending significant amounts of resources on Employee hiring, management and development (Hinkin \& Tarcey, 2000 as cited from Cheema \& Haq, 2017,p.677). Employee is the basic building block of organization and the primary vehicle for organization change (Ang, 2002 as cited from Cheema \& Haq, 2017, p. 677). Modern organization behavior theories proof that a happy employee is key element of organization success, and that motivated towards their organization. Motivated, committed, and satisfied employee perform better, which ultimately leads to improvement of employee morale and it is directly impact on organizational performance. (Cascio, 2006). Morale is a combination of attitudes towards the company, job, and the immediate supervisor (Khan \& Katz, 1953). The most important factor contributing employees morale are : relationship with the fellow workers, team spirit in direct work environment, working condition of work place ,leaves and holidays, salary, remuneration and benefits, management and employees are allowed to talk freely (Tiwari,2014,p.8). High morale contributes the high level of productivity, high returns to stakeholders, and employee loyalty. Low morale may cause high absenteeism and turnover. Respect, involvement, appreciation, adequate compensation, promotions, a pleasant work environment, and a positive organizational culture are the morale boosters. Many organizations offer diverse benefits to boost morale and satisfaction to the employees in their organization (Kongla, 2013 as cited from Tiwari, 2014, p.9). In this context, there is no doubt that high morale staff are the best assets of business enterprise. For writing this article, explore the actual morale situation of Nepal Airlines Corporation and its impact on organizational performance in Nepal.

\section{Statement of problem:}

Every organization in its aim to achieve its mission, vision and goals statements adopts some form of motivational strategies to entice their employees with high morale to give off their best. Some organizations assume that whatever motivational strategies they adopt would fit for every employee and bring about achievement of their performance targets. Numerous studies have been proof that worker and workplace environment highly influence morale of employees (Grau et al.,1992; Hull \& Azumi,1988; Koeske \& Kirk,1995; McKnight et al.,2001; Norsworthy \& abala,1982,1985, 1990;Reed,2002, and Straka,1993 as cited from Good and Huddleston, 2006,p.1). How to manager maintain or improve worker morale in the organization? Despite unanimous agreement in the existing literature about the significance and value of morale in influencing worker performance and its impact on 
productivity and production in the overall outputs or performance of the organization. In Nepal, identifying the factors that contribute to employee morale is particularly important for National Flag carrier.

Unsatisfied employee naturally poses the negative effect on performance. Nepal airline has expend once time-totime strikes. The major demands of these strikes taken together were primarily concerned with increment of benefits and facilities. Frequently, strikes give one the impression that there is sufficient room for frustration and dissatisfaction among the employees. At the same time, employee morale has decreasing due to the causes of low morale, which is directly impact on their service delivery and organization performance. Nepal airline facing the criticism from various sectors that the performance is no satisfactory due to the absent of high morale. Therefore, morale of the employees in Nepal Airlines have been taken as major problems for investigation under this research.

\section{Objectives of the study:}

The objectives of this study are:

1. To find out the level of morale of the employees of Nepal Airlines corporation in Nepal.

2. To evaluate the impact of Employee morale and on their organizational performance.

3. To find out the factors affecting on employee morale in the organization.

\section{Hypothesis:}

There is a significant impact of employee morale on organizational performance.

\section{Methodology:-}

To analyze the level of morale of the employees of Nepal Airlines Corporation and its impact on organizational performance. In order to achieve the objective, the relevant information and data have been collected from primary sources. Primary data was collected through the structured questionnaire survey from NAC employees and some key informants was interviewed with policy maker, academician, CEO, Executive committee, key personnel of NAC and others. The size of sample population was drawn 75 out of 1200 total permanent employees of NAC based on sample random sampling technique. Mixed methods both qualitative and quantitate used in this research. The research finding explains based on descriptive and analytical methods.

\section{The Review of Literature and Analytical Framework: Concept of Employee Morale:}

Employee morale is defined as the attitude, satisfaction, and overall outlook of employees during their association with an organization. Morale is "the state of the spirit of a person or group as exhibit by confidence, cheerfulness, discipline, and willingness to perform assigned task" (Perumal, 2011 as cited in Werang, 2012, p.437). Morale as the extent to which an individual's need are satisfied, and the extent to which individual perceives satisfied an stemming from the total job satisfaction (Bentley \& Rempel,1970;Brockington, 2003 as cited in Werang,2012,p.437). Furthermore, Leighton defined morale as the capacity as the group of people to pull together persistently and consistency in pursuit of a common purpose (as cited in Francis, 2010).

Morale is the most essential psychological state of mind of an individual, which is, convey in the form of selfconfidence, zeal and devotion towards an organization. Thus, Morale is viewed as a person's attitude towards being part of an organization and it reveals the satisfaction and the sense of accomplishment they obtain from being a part of group ( Khandhakumar \& Basasingh,2016 as cited in Aidoo et al., 2018, P.367). Similarly, employees' morale refers to the total viewpoints, attitudes, fulfilment, and self-assurance that they feel at work (Heathfield, 2018 \& Coughlan,1970).

Morale is an essential element of the organizational success for its mirrors the attitudes and opinions that both individual and groups have towards the organizational goals. High morale is demonstration by employee zeal, willing conformance with rules and instruction and readiness to interact with others in realizing organization goals. On the other hand, Low morale is demonstrated by aloofness, resistance, sentiments of discouragement and aversion of jobs (Aidoo et al., 2018, P.367).

\section{Concept of Organizational Performance:}

The concept of performance, as it appears defined in the dictionaries of French, English, Business, and so on defines more the ideas of outcome, achieved goal, quality and less the economic aspects of efficiency and effectiveness. Performance is a subjective perception of reality, which explains the multitude of critical reflections on the concept and its measuring instruments (Iuliana \& Maria, 2016, p.179). According to Didier (2002) believes that the 
performance consists in achieving the goals that the result of a comparison between outcome and objectives. Similarly, Michel Lebas (1995) explain the performance as future- oriented, designed to reflect particularities of each organization/ individual and is based on a casual model linking components and products. Furthermore, Rolstadas (1998) believes that the performance of an organization system is a complex relationship involving seven performance criteria that are: effectiveness, efficiency, quality, productivity, quality of work, innovation and profitability. Performance is closely related to the achievement of listed criteria, which can be regarded as performance objectives. According Neely et al. (2002) believes that performance should consider quantifying the efficiency and effectiveness of actions. He focused that performance is closely related to efficiency and effectiveness. A more comprehensive definition of performance is given by Brumbach (1988), which refers to both behavior and results. Behaviors are emanating from the performance and turn the performance of an abstract concept in to a concrete action(Brumbach 1988 as cited from Iuliana \& Maria, 2016, p.180). The above definition of performance can be translated in to another equivalent defining: performance is the comparison of an organization's goals and objectives with its actual performance in three distinct areas-financial performance, market performance, and shareholder.

\section{Factor Affecting on Employee Morale:}

Employee morale is a fundamental component of business operations- high morale coincides with job satisfaction, high work effort, creativity and initiative, a sense of pride in one's work, a commitment to one's organization and the desire to put the achievement of group ( common) goals ahead of personal goals, thereby enhancing an organizational performance (About,2003;Blum \& Naylor,1968; Griffin et al., 2004; Guion,1958; Hart et al., 2000; Parker \& Kleemier,1951, Smith \& Wakeley,1972, as cited in Linz et al., 2006). Again, Low morale, typically corresponding to high absenteeism, labour turnover, unresolved grievances or strikes, impedes the achievement of the organizational desired outcomes ( Burke \& Nelson,1998; Cappelli, et al.,1997; Firth et al.,2004; Makawatsakul \& Kleiner, 2003). Morale is very complex and purely emotional phenomenon and influence by various actors and factors in the organization these are objective of the organization, organizational design, personal factors, Rewards, Good Leadership and supervision, work culture and environment, capacity with fellow employees, job satisfaction \& opportunity to share profit. (Ravi \& Devi,2018,p.15000). The organization structure, reputation, image, goodwill, nature of work, Level of satisfaction, the level of supervision, worker perception of Rewards system, Employees educational level, employee's occupational level, quality of work life and other financial and non-financial factors pay the vital role to maintain the high morale in the organization (Ravichandran \& Balakumaran (2019) .

\section{Empirical Literature on Employee morale:}

James \& Rhonda (1996) conducted a study on "A new look at factor related to college faculty morale" at Tennessee State University. The finding was found there was significantly linked between workload, working conditions and relations between faculty and the administration. They also find out salary has no relationship with morale. Similarly, the research conducted by Stephanie Litton Potter (2012), entitled "Relationship between educators, organization commitment, Job satisfaction, and administrators" The finding shows that there is no significant relationship between gender, job satisfaction, and their organizational commitment. Again, Haynes (2008) explain the behavioral office environment behavioral component of the office environment that have the greatest impact on office productivity. In all of the work patterns, it was found that interaction was perceived to be the component to have the most positive effects on productivity and distraction was perceived to have a most negative. Furthermore, Usmani et al. (2013) explores the relationship between diversity and customer satisfaction mediated by employee morale. Exploratory Factor Analysis, Confirmatory Factor Analysis and Structural Equation Modeling were using for test the relationship and significant of the model. The finding rejected the mediated relationship of diversity and customer satisfied but showed positive association between diversity and employee morale. Similarly, Tiwari (2014), conducted research on "A study on Employee Morale and Its impact on employee Efficiency at Jaya Cement Rewa M.P." The finding of the study shows that significant relationship between employee morale and its impact on employee efficiency.

Hillary (2018) conducted another, study, on "The effect of the Employee Relation on Employee Morale". The finding of the study shows that there are positive relationship between employee relation and employee morale.

Furthermore, Kandhakumar (2016), research on"Conceptual Framework on Employee morale and satisfaction in workplace". The finding shows that best working environment has directly impact of high morale in the organization. 
Zial (2011) concluded is that teambuilding has long-term positive relationship between employee morale and employee retention. Team performance, individual contribution, team evaluation and coordination have long terms positive impact on employee morale and employee retention. The unity has no significant effect on employee morale and employee retention.

Employee morale within an organization has a direct impact on the satisfaction level of its customer and the organization ultimately success. When the relationship-based leaders promote core competency development of its workforce throughout the organization, an opportunity exists for ensuring high employee morale and customer satisfaction, an increase in employee and customer retention rates, and a positive long-term outlook for the organization's successful performance (Barbara,2002, as cited in Tiwari, 2014, p.10).

\section{Analysis And Discussion:- Morale of employees:}

Morale is also viewed an important quality in both individual and organization. Morale represents the attitude of individual and group in an organization towards their work environment. Morale is an inductor of the attitude of employees towards their job, superiors and their organization environment. It is a collection of employee's attitude, feelings and sentiments. In the organization get happiness, personnel adjustment, positive attitude, and we feeling etc. in NAC staff that determine the level of Morale of the employee of NAC. Which statement of morale and value of achievement was details given in below in table- 1

Table 1:- Statement of Morale in NAC

\begin{tabular}{|l|l|l|l|c|}
\hline Statement of Morale & Highly satisfied (\%) & $\begin{array}{l}\text { Satisfied } \\
(\%)\end{array}$ & $\begin{array}{l}\text { Not satisfied } \\
(\%)\end{array}$ & Total (\%) \\
\hline Get happiness in NAC & 26.67 & 40 & 33.33 & 100 \\
\hline Good personnel adjustment & 26.67 & 40 & 33.33 & 100 \\
\hline "We" feeling & 24 & 37.33 & 38.67 & 100 \\
\hline Positive attitude of NAC staff & 32 & 38.37 & 29.33 & 100 \\
\hline Feeling success and satisfaction & 20 & 27 & 53 & 100 \\
\hline Excitement \&enthusiasm about job & 22 & 31 & 47 & 100 \\
\hline Organization inspiration for the employees & 19 & 26.40 & 54.60 & 100 \\
\hline Organizational Respect for the Employee. & 20.60 & 34.20 & 45 & 100 \\
\hline
\end{tabular}

(Source: Field Study, 2014)

In above table No.1, $66.67 \%$ of NAC employees were getting optimum happiness in NAC service, and $66.67 \%$ were feeling good personnel adjustment getting in NAC. Similarly, $61.33 \%$ of respondents was felling "we felling" environment and $70.37 \%$ have positive attitude towards the NAC staff in the organization. Furthermore, the rate of felling success and satisfaction in the organization was found $53 \%$ unsatisfied and excitement \& enthusiasm was found $47 \%$ unsatisfied. Again, 54.60\% of respondents was found unsatisfied their origination inspiration policy for the employees and $45 \%$ of respondent found dissatisfaction for their organizational respect for the employees in NAC.

In above analysis shows that NAC has been providing optimum happiness and good personal adjustment in organization and positive attitude of NAC employees regarding their job but feeling success and satisfaction, excitement and enthusiasm about job and organizational inspiration for the employees in the organization was found highly dissatisfied. Hence, the NAC need to be correction their management behavior and practice for ensuring high morale and high performance in the organization.

\section{Measurement statement of Morale:}

Morale is an exclusive thing. It is depend up on individual or group behaviours. There are some sorts of measuring factors, statement or behavior about morale, which is given below in table No. 2

Table no 2:- Measurement Statements of morale in NAC

\begin{tabular}{|l|l|l|l|l|}
\hline Measurements tools for morale & $\begin{array}{l}\text { Highly satisfied } \\
(\%)\end{array}$ & $\begin{array}{l}\text { Satisfied } \\
(\%)\end{array}$ & $\begin{array}{l}\text { Not satisfied } \\
(\%)\end{array}$ & $\begin{array}{l}\text { Total } \\
(\%)\end{array}$ \\
\hline Working condition of the employees & 46.27 & 36.73 & 17 & 100 \\
\hline
\end{tabular}




\begin{tabular}{|l|l|l|l|l|}
\hline Salary and others benefits & 10 & 44 & 46 & 100 \\
\hline Leaves and holidays & 33 & 52 & 15 & 100 \\
\hline $\begin{array}{l}\text { Management encourage and development of the } \\
\text { employees }\end{array}$ & 18 & 35 & 47 & 100 \\
\hline Take care health\& security & 28 & 39 & 33 & 100 \\
\hline Safety and welfare measure & 36 & 35 & 29 & 100 \\
\hline Labour turnover & 26.67 & 45.33 & 28 & 100 \\
\hline Employees absenteeism & 18.67 & 42.67 & 38.66 & 100 \\
\hline Antagonism & 26.67 & 34.67 & 38.66 & 100 \\
\hline Quality and quantity of output & 32 & 28 & 40 & 100 \\
\hline
\end{tabular}

(Source: Field Study, 2014)

In above table No.2 shows that $83 \%$ of respondents was satisfied their working condition of the employees in the organization and $54 \%$ employee only satisfied their salary and others benefits. Similarly, $85 \%$ was satisfied their leaves and holidays facilities but $47 \%$ was dissatisfied their management encourage and development policy of the employees. Furthermore, $67 \%$ of employees were satisfied on their healthcare and job security policy and $71 \%$ were agree their best safety and welfare measure in the organization. Again, labour turnover rate was $28 \%$, Employees absenteeism and antagonism both were found $38.66 \%$ and quality and quantity of output ratio was $60 \%$.

The above phenomenon shows that, the rate of employee turnover, antagonism and absenteeism determine the overall health of the NAC and determines the rate of satisfaction of the employee in the organization. Which is directly impact of employee's morale and organizational performance. Due to the lack of such types of problems a staff feeling high frustration in the organization and its impact on their absenteeism and antagonism in the organization. Which is directly and indirectly hamper or decrease quality and quantity output or performance of NAC

Indicators for organizational culture for high morale:

High morale is a great importance for management and its employees for achieving organizational goals with their predetermined objectives. It generally indicate attainment of organization commitment, culture, leadership styles, environment and others, which is given in below table no- 3 .

Table No 3:- Indicators of organizational culture for high morale

\begin{tabular}{|l|c|c|c|c|}
\hline Indicators of organization culture & Highly satisfied (\%) & $\begin{array}{l}\text { Satisfied } \\
(\%)\end{array}$ & $\begin{array}{l}\text { Not } \\
\text { satisfied } \\
(\%)\end{array}$ & Total \\
\hline Organization objective & 25.33 & 41.33 & 33.34 & 100 \\
\hline $\begin{array}{l}\text { Loyalty toward organization \& } \\
\text { leadership }\end{array}$ & 38.67 & 33.33 & 28 & 100 \\
\hline Strong organization stamina & 25.33 & 34.67 & 40 & 100 \\
\hline Initiation of achieve organizational goals & 34.67 & 37.33 & 28 & 100 \\
\hline Achievement of the organizational goals & 28 & 34.67 & 37.33 & 100 \\
\hline High degree of interest in job & 20 & 30 & 50 & 100 \\
\hline Job placement system & 17.33 & 30.67 & 52 & 100 \\
\hline
\end{tabular}

(Source: Field study, 2014)

The table No.3 shows that $66.66 \%$ of employees only clear about their organization's plan, policy, programme, objectives, and $72 \%$ respondent's loyalty towards their organization and Leadership. Similarly, $60 \%$ of employee found strong organization stamina and $72 \%$ of taking initiation of achieving organizational goals in NAC. Furthermore, only $62 \%$ employees were agreed to achievement successfully goals of NAC and $50 \%$ of employees of NAC did not have interest on their job. Again, 52\% of employees dissatisfied their job placement system.

In above analysis shows that most of employees does not liked their interest in the job and dissatisfied their job placement system. Which is directly impact on employee's morale and organizational performance so that NAC need to be improve their human resource planning including placement, transfer, training etc. according to the 
interest, capacity, knowledge, skills experience and qualification. The level morale of NAC employee is satisfactory but not such a high.

\section{Factors Affecting on High Morale:}

High morale exists when the employee's attitudes are favorable to the total situation of a group and individual to the attainments of its objectives. There are some sorts of factors affecting on employee morale in the organization, which is given below in table no- 4

Table no 4:- Factors affecting on high morale of the employees

\begin{tabular}{|l|l|l|l|l|}
\hline Factors of impact on high morale & $\begin{array}{l}\text { Highly } \\
\text { impacted }(\%)\end{array}$ & $\begin{array}{l}\text { Impacted } \\
(\%)\end{array}$ & $\begin{array}{l}\text { Total } \\
(\%)\end{array}$ \\
\hline Permanent and secured job & 60 & 20 & 20 & 100 \\
\hline Fair and sound promotion policy & 56 & 26.67 & 17.33 & 100 \\
\hline Good relationship with superior & 57.33 & 26.67 & 16 & 100 \\
\hline Relationship with subordinator & 72 & 18.67 & 9.33 & 100 \\
\hline Congenial work load & 20 & 45.80 & 34.20 & 100 \\
\hline Management and employee relations & 15 & 28 & 57 & 100 \\
\hline Supervisor encourage special talent & 3 & 20 & 77 & 100 \\
\hline Channel of communication & 42.67 & 30.67 & 26.66 & 100 \\
\hline Situation of training & 21.33 & 21.33 & 57.34 & 100 \\
\hline Job satisfaction & 25.33 & 40 & 34.67 & 100 \\
\hline Team spirit in direct work environment & 13 & 47 & 40 & 100 \\
\hline $\begin{array}{l}\text { Clear vision for the future for your } \\
\text { company }\end{array}$ & 7 & 41 & 52 & 100 \\
\hline
\end{tabular}

(Source: Field Study 2014)

In above table No.4 shows that $80 \%$ of NAC employees were agreed permanent and secured job ensuring the high morale of the employee and $82.67 \%$ was said that fair and sound and fair promotion policy impact on high morale. Similarly, $84 \%$ of employees agreed on good relationship with superior and $90.67 \%$ agreed on relationship with subordinator role have directly impact on ensuring high morale employees. Again, 65.80\% of employee focused on congenial workload and only $43 \%$ of employee determine the management and employees relations impact on employee morale. Furthermore, $77 \%$ of employees did not have any get any encourage from supervisor to special talent in NAC. On the other hand, $73.34 \%$ of employees were agreed channel of communication impact of morale and $57.34 \%$ of respondents dissatisfied their training impact on morale in the organization. The level of job satisfaction affect morale, which was found $65.33 \%$ and team spirit in direct work environment, was found $60 \%$. At last, the clear vision for the future for your company also impact on employee's morale that was only found $48 \%$ in a whole.

In above context, Employee's morale depends on nature of job, job security, fair and sound promotion system, relationship between supervisor, subordinator, management, and employee, job satisfaction, workload, channel of communication, friendly working culture, situation of training and career development, Team spirit, organizational behavior, clear vision for organizational future and so on. All of them supervisor encourage special talent, management employee relationship, job satisfaction and clear vision for organization future of NAC was found unsatisfied.

\section{Employees Feeling about the Job:}

Job is an important part of all human being. Job is an important instrument of earning method for generating income. Without any income, human life cannot be survival. In this context, every employees want to be good environment, secured workplace and permanent nature of job and fair and sound promotion system etc. that was impact on employee feeling about job and its impact on employee morale. Which is given below in table no- 5 .

Table 5:- Employees Feeling about the Job

\begin{tabular}{|l|l|l|l|l|}
\hline Feeling about the job & $\begin{array}{l}\text { High interested/Very } \\
\text { Good }(\%)\end{array}$ & $\begin{array}{l}\text { interested / good } \\
(\%)\end{array}$ & $\begin{array}{l}\text { not interested/ } \\
\text { Not so good }(\%)\end{array}$ & $\begin{array}{l}\text { Total } \\
\text { Interesting in NAC service }\end{array}$ \\
\hline
\end{tabular}




\begin{tabular}{|l|l|l|l|l|}
\hline Prestige of NAC in the society & 52 & 20 & 28 & 100 \\
\hline Organization culture & 32 & 26.67 & 41.33 & 100 \\
\hline Obstacle of social life & 56 & 14.67 & 29.33 & 100 \\
\hline Satisfied about promotion policy & 25.33 & 18.67 & 56 & 100 \\
\hline
\end{tabular}

(Source: Field Study, 2014)

In above table No.5 shows that $77.33 \%$ of employees interested in NAC service and $72 \%$ of employees get respect form society due to the job of NAC. Similarly, $58.67 \%$ of employees, feeling satisfied their organizational culture and $70.14 \%$ were not feeling social obstacle of social life due to NAC employer. At last, only $40 \%$ of employee were satisfied their promotion policy.

In above context, interest of NAC service and prestige is highly satisfied and respectable in the society but organization culture and promotion policy of the organization of NAC was found dissatisfied so that NAC need to be create sound administrative culture and fair and merit based promotion policy.

\section{Knowledge about the NAC rules and regulation:}

Organization was established by certain rules and regulation. The rules and regulations provide basic knowledge about certain rules, regulation, provisions of service, facilities and compensation of employees and organization procedures. Without these knowledge employees have darkness or blind in the organization and its impact on ambitious or frustration due to the policy celerity. Hence, NAC established by special Act, 2019 and conducted by Employee Service Rules, 2058 and other related Act, rules and regulation. In this context, employee's knowledge about the rules and regulation which, is given below in table no.-6.

Table 6:- Knowledge about the NAC rules and regulation

\begin{tabular}{|l|l|l|l|l|}
\hline Knowledge about NAC rules \& regulation & Clear (\%) & Little bit clear (\%) & Not clear at all (\%) & Total (\%) \\
\hline Clear bout NAC rules and regulation & 61.33 & 28 & 10.67 & 100 \\
\hline Code of conduct & 53.33 & 29.33 & 17.34 & 100 \\
\hline Goals or objectives & 68 & 20 & 12 & 100 \\
\hline Duties and responsibilities & 84 & 9.33 & 6.67 & 100 \\
\hline Provision of punishment reward & 60 & 18.67 & 21.33 & 100 \\
\hline
\end{tabular}

(Source: Field Study, 2014)

In above table No.6 shows that $61.33 \%$ of NAC employees have sufficient knowledge, $28 \%$ have little-bit knowledge, $10.67 \%$ have no knowledge about their rules, and regulation and only $53.33 \%$ have a knowledge of employee code of conduct. Similarly, $68 \%$ of employee have a clear knowledge of organization goals and objectives and $84 \%$ of employee's knowledge about their duties and responsivities in their organization. Furthermore, the clear knowledge about the provision of reward and punishment was found $60 \%$ of employees in the organization.

In above context, most of the NAC employees have a basic knowledge about NAC rules and regulation.

Factors Improve the level morale for better achievement:

Motivation and morale are interrelated cannot be separated each other. High motivation leads to high morale and both factors are leads to high performance with better achievement in the organization. In this study, also try to find out some extended factors to improve the level of morale for better achievement. Which is given below in table no-7.

Table no 7:- Factors improve the level morale for better achievement

\begin{tabular}{|l|l|l|l|l|}
\hline Improved the level of motivation \& morale & $\begin{array}{l}\text { Highly } \\
\text { Agree (\%) }\end{array}$ & Agree (\%) & Disagree (\%) & Total \\
\hline Increasing excising monetary rewards & 80 & 13.33 & 6.67 & 100 \\
\hline Fair and sound promotion policy & 78.67 & 13.33 & 8 & 100 \\
\hline Plan \& policy for individual growth \& dev. & 77.33 & 13.33 & 9.34 & 100 \\
\hline Effective feedback system & 78.67 & 14.67 & 6.66 & 100 \\
\hline Develop the positive attitude of employees & 76 & 18.67 & 5.33 & 100 \\
\hline Implementation of rules and regulations & 70.67 & 17.33 & 12 & 100 \\
\hline
\end{tabular}




\begin{tabular}{|l|l|l|l|l|}
\hline Delegations of power and authority & 76 & 17.33 & 6.67 & 100 \\
\hline Effective information system & 72 & 21.33 & 6.67 & 100 \\
\hline Employee participation on p level & 72 & 16 & 12 & 100 \\
\hline Strictly implementation of reward \& punishment & 74.67 & 17.33 & 8 & 100 \\
\hline $\begin{array}{l}\text { Employee morale impact on organization } \\
\text { performance }\end{array}$ & 50.20 & 41.80 & 8 & 100 \\
\hline
\end{tabular}

(Source: Field Study, 2014)

In above table No.7 shows that $80 \%$ of employees highly agreed for increasing excising monetary reward and 78.67 $\%$ of employee were highly agreed fair and sound promotion policy help to ensuring high morale in the organization. Similarly, the plan and policy for individual growth and development impact on high morale was found $77.33 \%$ and effective feedback system ensuring morale was found $78.67 \%$. Again, $76 \%$ of employees were highly agreed to develop the positive attitudes of employees to ensuring the high morale and $70.67 \%$ of employee agreed for implementation of rules and regulations effectively. Furthermore, $76 \%$ of employees believes on delegation of power and authority impact on assured morale. Hence, $72 \%$ of employees were supported both effective communication system and participation on policymaking process ensuring high morale. At last, strictly implemented on reward, punishment system has highly impact on morale, which was found $74.67 \%$, and employee morale impact on organization performance was found highly significant $92 \%$.

In above context, most of the NAC employees were agreed above statement for improved the level of employee's morale for better performance.

\section{Conclusion:-}

Study show the employees morale and its impact on organizational performance at Nepal Airlines Corporation in Nepal. The average percentage score has been computed (92\%). Morale is psychological concept. All individual are having different level of Morale.

Morale may be range from very high to very low form different context. The research shows various factors influences of employee's morale and employee's productivity and its impact of overall organizational performance. These most important factor contributing employees morale are: salary and remuneration, job security, social security measures, welfare facilities, leaves and holidays, safety and health condition, organizational culture and climate, working environment, channel of communication, relations between supervisor, subordinator, management and employees, delegation of power and authority, participation on decision making process, rewards and punishment system, fair and sound career development or promotion system, recognition of work, properly implemented code of conduct, feeling success and job satisfaction, prestige of job in the society, effective feedback system, plan for individual growth and development, positive attitude towards the employees, organization respect for the employees, excitement \& enthusiasm about job, organization inspiration for the employees, we feeling, Team spirits in direct work environment, job placement, high degree of interest in job, organizational leadership, labour turnover, employees absenteeism, antagonism, quality output, and get happiness in organization etc. was found important factors for determines the employees morale in the organization. To conclude that high or good employee morale plays vital role in every organization for better performance. Unless an employee has low or poor morale if always, a possibility of employee conflict, disharmony, lack of effectiveness, efficiency, production, and productivity and affect smooth running of the organization and its performance.

\section{Reference:-}

1. Abbott, J. (2003). Does Employee Satisfaction Matter? A Study of determine whether Low Employee Morale affects Customer Satisfaction and Profits in the business-to-business sector. Journal of Communication Management, Vol.7, No.4, pp.333-339.

2. Aidoo, E., Donkor, J. \& Odoi, A.(2018). Effect of Employee Morale on Productivity in the Ghanaian Public Sector. The Mediating Role of Delegation. Archives of Business Research, Vol.6, No.8, pp.365-375.

3. Ang, A. (2002). An eclectic review of the multidimensional perspectives of employee involvement. The TQM Magazine, 14 (3), pp.192-200.

4. Barbara, J.F. (2002). Promoting Organizational Competency: A Solution to Increasing Employee Morale and Customer Satisfaction. CERES Innovation, pp.1-9. 
5. Blum, M.L. \& Naylor, J.C. (1968). Industrial Psychology-Its Theoretical and Social Foundations, McGraw, Hill, New York, NY.

6. Brockington, R.W.C. (2003). A Comparative Analysis of Elementary, Middle and High School Teachers Morale. Unpublished doctoral dissertation, University of South Carolina State, Orangeburh, South Carolina.

7. Burke, R.J. \& Nelson, D. (1998). Merger, Acquisitions Downsizing, and Privatization: A North American Perspective. In Growing, M.K. et al. (Eds.). The New Organization Reality: Downsizing Restructuring, and Revitalization. American Psychological Association, Washington D.C., pp.21-54.

8. Cappelli, P., Bassi, L., Katz, H.,Knoke, D., Osterman, P.\& Useem, M. (1997). Change at Work. Oxford University Press, New York, NY.

9. Cascio, W. (2006).The new human capital equation. The Industrial Organizational Psychologist, 44(2), pp.1522.

10. Cheema, J.R. \& Asraf- ul Haq, M. (2017). Effects of Staffs Participation, Morale and Shortage on organizational performance: An International Survey, Issues in Educational Research, Vol. 27, No.4, pp.677696.

11. Coughlan, R. J. (1970). Dimensions of Teacher Morale. American Educational Research Journal, Vol.7, No.2, pp.221-234.

12. Didier, N. (2002). Manager les Performance (Managing Performance). Insep Consulting Editions, Paris.

13. Firth, L., Mellor, D.J., Moore, K.A. \& Loquet, C. (2004). How can managers reduce employee intention to quit? Journal of Managerial Psychology, Vol.10, No.2, pp.170-187.

14. Francis, A. (2010). The Concept of morale. Retrieved from :htt//

15. Grau, L., Columbotos, J. \& Gorman, S. (1992). Psychological morale and job satisfaction among homecare workers who care for Persons with AIDS. Women and Health, Vol.18, No.1, pp.1-21.

16. Griffin, M.A., Rafferty A.E. \& Mason, C.M. (2004). Who Started this? Investigating different sources of Organization Change. Journal of Business and Psychology, Vol.18, No.4, pp.555-570.

17. Guion, R.M. (1958). Industrial Morale: The problem of Terminology. Personnel Psychology, Vol.11, pp.59-61.

18. Hart, P.M., Wearing, A.J., Conn, M. Carter, N.L. \& Dingle, R.K. (2000). Development of the School Organizational Health Questionnaire: A measure for assessing teacher Morale and School Organizational Climate. British Journal of Educational Psychology, Vol.70, PP.211-228.

19. Haynes, B.P. (2008). An Evaluation of the Impact of the Office Environment on Productivity. Journal of Facilities, Vol.26, Issue.5/6, pp.178-219.

20. Heathfield, S.M. (2018). You can boost employee morale. Available: https://www.thebalancecareers.com/you_can_boos_employee_morale-1918107.

21. Hinkin, T.R. \& Tarcey,J.B.(2000). The cost of turnover: Putting a practice on the learning Curve. Cornell Hotel and Restaurant Administration Quarterly, Vol. 41, No.3, pp.14-21.

22. Hull, F. \& Azumi, K. (1999). Technology and Participation in Japanese Factories. Work and Occupation, Vol.15, No.4, pp.423-447.

23. Iuliana, I.E. \& Maria, C. (2016). Organizational Performance - A concept that Self-seeks to find Itself: Analysis of the constantin Brancusi. University of Targu Jiu. Economy Series, Issue. 4, pp.179-183.

24. James, H. Stewart \& Rhonda, S. (1996). A New look at factors related to college faculty Morale. Educational Research Quarterly.

25. Khan, R.L. \& Katz, D.(1953). Leadership Practice in Relation to Productivity and Morale. In Cartwright, D. and A. Zander (Eds.) Group Dynamic, Row Peterson \& Co. Evanston, IIIionis, p.616.

26. Khandhakumar, P. \& Basasingh, J.I. (2016). Conceptual frameworks on Employee Morale and Satisfaction in Workplace. International conference on Innovative Management Practice, Vol.1, Issue.1, pp.312-318.

27. Koeske, G. F. \& Kirk, S.A. (1995). The Effect of Characteristics of Human Service, Worker on Subsequent Morale and Turnover. Administration in Social Work, Vol.19, No.1, pp.15-31.

28. Kongla, R.P.(2013). Motivation and Workforce Performance in Indian Industries. Res. J. Management Sci. Vol.2 (4). pp. 25-29.

29. Lebas, M. J. (1995). Performance Measurement and Performance Management, International Journal of Production, Vol.41, No.1-3.

30. Linz, S.J., Good, L.K. \& Huddleston, P. (2006). Worker Morale in Russia: An Exploratory Study. Journal of Managerial Psychology, Vol.21, No.5, pp.415-437.

31. Makawatsakul, N. \& S. K. Kleiner, B.H. (2003). The effect of downsizing on morale and attrition. Management Research News, Vol.26, pp.52-62. 
32. McKnight, D., S. \& Schroeder, R. (2001). When do feedback, Incentive control and Autonomy improve morale? The Importance of Employee-Management Relationship Closeness. Journal of Managerial, Vol.13, Issue.4, pp.466-482.

33. Neely, A.D., Adams, C. \& Kennerly, M. (2002). Performance Prism: The Scorecard for Measuring and Managing Stakeholder Relationships, Prentice-Hall Financial Times, Harlow.

34. Norsworthy, J.R. \& Zabala, C.A. (1982). A Note on introducing a measure of worker attitude in cost function estimation. Economic Letters, Vol.10, pp.185-191.

35. Norsworthy, J.R. \& Zabala, C.A. (1985). Worker attitudes, Worker behavior, and Productivity in U.S. Automobile Industry 1959-1976. Industrial and Labour Relations Review, Vol.38, No.4, pp.544-447.

36. Norsworthy, J.R. \& Zabala, C.A. (1990). Worker attitudes and the cost of Production: Hypothesis tests in an Equilibrium Model. Economic Inquiry, Vol.28, No.1, pp.57-78.

37. Panthi, Rishikesh (2019 a). Performance of Nepal Airlines Corporation and Its operational challenges in Nepal. ACADEMIA An International Multi-disciplinary Research Journal, Vol.9, Issue.3, pp.46-64.

38. Perumal, M. (2011). Key Strategies to raise teacher morale and improve School Climate. Retrieved from: htt://www.google.com.

39. Ravi, A.G. \& Devi, P.S. (2018). A Study on Employee Morale with Special Reference to Butterfly Gandhimathi appliance Pvt. Ltd. International Journal of Pure and applied Mathematics, Vol.119,No.12, pp.1499315010.

40. Ravichandran, M. \& Balakumaran, A. (2019). Factors Affecting Employee Morale in the Indian Automobile Industry- A Literature Review. International Journal for Research Applied Science and Engineering Technology (IJRASET), Vol.7, Issue. III.

41. Reed, K. (2002). The use of Correspondence Analysis to Develop a Scale to Measure Workforce Morale from Multi-level Data. Social Indicators Research, Vol.57, pp.339-351.

42. Rolstadas, A. (1998). Enterprise Performance Measurement. International Journal of Operations and Production Management, Vol.18, No.9-10.

43. Stephanie, L. P. (2012). Relationships between Educator's Organizational Commitment, Job Satisfaction, and Administrators. Gender Doctoral Thesis Submitted to Liberty University, Lynchburg, VA.

44. Straka, J.W. (1993). Is Poor Worker Morale Costly to Firms? Industrial and Labour Relations Review, Vol.46, No.2, pp.381-394.

45. Tiwari, Usha (2014). A Study on Employee Morale And Its Impact on Employee Efficiency at Jaypee Cement Plant Rewa (M.P). Abhinav International Monthly Refereed Journal of Research in Management and Technology, Vol.3, Issue.11, pp.8-14.

46. Usmani, S., Kumari, K. \& Hussain, J. (2013). Diversity, Employee Morale and Customer Satisfaction: The Three Musketeers. Journal of Economics, Business and Research, Vol.5, pp.369-373.

47. Werang, B.R. (2012). Teachers' Scio-economic Status and Its Relationship with Teachers work Morale and Teacher Job Performance at State Senior High Schools in Merauke Regency- Indonesia. International Journal of Science and Research (IJSR), Vol.3, Issue.8, pp.436-440.

48. Zial, Sayma (2011). Effects of Organizational Team Building on Employees' Morale and Job retention. Business Management Dynamics, Vol.1 (7), pp.31-37. 